Austral Cmunicación

Volumen 10, número 1 (junio de 2021): e7-e9

ISSN (I) 2313-9129. ISSN (E) 2313-9137

\section{Tim Wu}

\section{Comerciantes de atención}

Madrid, España, Capitán Swing, 2020, 499 pp. ISBN: 9788412064599.

Es muy probable que no seamos conscientes de que, a diario, de manera constante, una multiplicidad de empresas, de numerosos sectores y ámbitos territoriales, lucha por atraer y conservar nuestra atención durante el mayor lapso de tiempo posible. Tales entidades, una vez lograda nuestra atención, obtienen ciertos datos con el objetivo de hacer suculentas ganancias a partir de ellos. De esta manera, se crean determinados perfiles dentro de los que se nos integra -en función de la edad, sexo y preferencias de índole personal-. De hecho, en el ámbito de los buscadores, se hizo relativamente popular la frase de que Google sabe más de nosotros que nosotros mismos. Así, sabe dónde vives, qué modelo de teléfono posees, cuáles han sido tus últimos movimientos, en qué medio de transporte, tus gustos, tus búsquedas, aplicaciones favoritas, etc.

La industria de la atención acumula cada vez un mayor número de horas de las personas. Y, lo que es más relevante, no sólo del ámbito público, sino del privado $\mathrm{y}$, a mayor abundamiento, el personal. Como la realidad cotidiana pone de manifiesto, la publicidad, la televisión, o las redes sociales captan una gran parte de nuestra atención. Existe un creciente bombardeo de estímulos. Cabría preguntarse entonces que si, a título de ejemplo, no podemos dejar de mirar, de manera compulsiva, nuestro terminal móvil. ¿Quién está, en realidad, tomando las decisiones?

El autor de la obra es Tim Wu, es académico de la Universidad de Columbia Estados Unidos- y colaborador habitual del The New York Times. Es un reconocido experto en la industria de medios y de tecnología. Cuenta con importantes reconocimientos. Así, en 2006, fue nombrado, por parte de la revista Scientific American, una de las personas más influyentes, y en 2007 fue considerado, por la revista 02138 , uno de los 100 graduados más influyentes de la Universidad de Harvard. En 2016, fue parte del Consejo Económico Nacional de la Casa Blanca. Ha sido merecedor, hasta en dos ocasiones, del premio Lowell Thomas.

Hace más de un siglo que la industria está acometiendo numerosas actividades con el objetivo de captar nuestra atención. Todo ello resulta visible en los periódicos más antiguos que se vendían a un centavo en los Estados Unidos (que fueron los que dieron origen a los anuncios publicitarios) hasta la televisión o Internet. Las empresas que operan en este ámbito -que son muy numerosas- buscan obtener beneficios de los datos que consiguen como consecuencia de captar nuestra atención y el tratamiento informático de los mismos.

En cuanto a su sistemática, la obra se estructura en cinco grandes bloques que, a continuación, analizaremos de forma somera. Todo ello gira en torno a los comerciantes de atención que, a su vez, da título a la monografía. Estos tienen como objetivo tener nuestra atención y seguidamente mercantilizarla. En el supuesto de que traten de ofrecerte algo de manera gratuita, en realidad, el producto eres tú mismo.

La primera parte, que tiene por rúbrica "Maestros de centelleantes modernidades", 
se refiere al fenómeno publicitario y de sus mejoras por depurar la comunicación. Así, alude a los anuncios que originariamente se realizaron para los productos milagro, pasando por el tabaco, elixires bucales y productos dentífricos. Especialmente sugerentes son las valoraciones que se formulan de Claude C. Hopkins que, como señaló el publicista Drayton Bird: "si la industria de la publicidad ha dado alguna vez un genio como la copa de un pino, este ha sido Hopkins”. De Hopkins, podemos citar una obra de referencia cual es Mi vida en publicidad, Ediciones Eresma, 1980. Aunque, a priori, esta última parece una autobiografía, el autor señala que su objetivo era que su libro sirviera no tanto como una historia personal, sino como una historia empresarial para, según decía de manera textual, "enseñar el arte de la publicidad".

La conquista del tiempo y del espacio da nombre a la segunda parte de la monografía. En esta se describe el paso de la industria publicitaria decimonónica presente en las calles -generalmente en vallas publicitarias o muros- e incluso el servicio postal a la novedosa radio o la televisión de la época, lo cual ya suponía una entrada más invasiva en nuestros hogares. En los primeros treinta años del siglo XX, se puso de manifiesto que la atención se podía alcanzar a gran escala a un nivel de poder comercial y militar sin precedentes conocidos. En ese momento existía cierta brecha entre la esfera pública o social -fuertemente comercializada- y la vida privada que se desarrollaba en el interior de los hogares. De alguna manera, los hogares parecían, en un principio, estar a salvo del bombardeo comercial que imperaba. Todo ello cambió con la radio y la televisión.

La tercera parte de la obra se refiere a lo que Wu denomina "La tercera pantalla". En esta analiza la red de redes donde explica cómo la industria de la atención llegó de las casas a los computadores. Desarrolla los orígenes de la Red y al caso de AOL -American Online-. Desde los años setenta hasta los noventa del siglo pasado, la televisión era la reina indiscutible del mundo occidental, por lo que respecta a la captación de la atención humana. Una vez que los ordenadores captaron nuestra atención, de alguna forma, nos engancharon para siempre. En este orden de cuestiones, no podemos perder de vista el efecto disruptivo que en este ámbito supuso el correo electrónico. Este último fue la primera aplicación rompedora de internet $\mathrm{e}$ incluso el programa que quizás justificase el coste de toda la red. Especialmente sugerentes resultan las apreciaciones que el autor realiza -aunque podrían haberse abordado con más profundidad- respecto a los videojuegos y sus orígenes que vincula con Ralph Baer en 1972. Este último creo un rudimentario aparato que sería la antesala de las videoconsolas -Magnavox Odyssey-. Como Wu pone de manifiesto, en la década de los noventa del siglo pasado, AOL puso de relieve que el mayor atractivo de las nuevas redes informáticas era de carácter social: se trataba de la posibilidad de interactuar con otras personas.

El bloque cuarto -que lleva por título "La importancia de ser famoso"- versa sobre como lo individual y lo personal se ha convertido como una mercancía que tiene valor por sí mismo. La alineación que efectuó AOL de la entrada de la nueva tecnología en los hogares estadounidenses con un nuevo interés social de la gente no tuvo lugar al margen del contexto cultural. De hecho, así acontece con cualquier innovación tecnológica.

Finalmente, el último bloque nos lleva a cómo son las cosas en la actualidad y cómo 
Austral Comunicación

Volumen 10, número 1 (junio de 2021): e7-e9

ISSN (I) 2313-9129. ISSN (E) 2313-9137

podrán a ser realmente en el futuro. Hay tres puntos de este espacio que, por su interés, conviene precisar. En primer lugar, hacemos un uso permanente de la cuarta pantalla que puede ser compulsivo: el del smartphone. En segundo lugar, la tecnología ya no puede ser reputada como un fin de la atención, sino que es un medio para lograr la atención y obtener determinados datos que, posteriormente, serán procesados de manera informática. Por último, el hecho de tener un espacio y un poder en virtud de los cuales poder negociar con la industria que, como hemos visto, ha cambiado, de manera sustancial, las reglas del juego.

En definitiva, la obra a la que nos hemos referido representa una monografía de extraordinaria relevancia sobre la atracción de la atención y los sugerentes efectos que conlleva. Cabe referirse a dos grandes conclusiones que se derivan de la lectura. En primer lugar, debemos ser conscientes de que sería deseable un pacto entre los individuos de la sociedad y la industria que está experimentando un elenco realmente notable de beneficios. En segundo lugar, sería positiva una mayor transparencia. En palabras de $\mathrm{Wu}$, habría que zonificar o reconquistar los espacios de influencia de esta industria que ha pasado de un espacio marcadamente público a una órbita privada. Existe una industria que, desde hace más de un siglo, está depurando sus técnicas con el objetivo de seducirnos.

Patricia Vargas Portillo

ESIC Business \& Marketing School, Madrid, España

jennypatricia.vargas@esic.edu

ORCID: https://orcid.org/0000-0002-0226-3053 